\title{
SHM SUPPORTING DAMAGE TOLERANCE DESIGN PHILOSOPHY AS A CHALLENGE FOR DESIGNERS OF FUTURE AIRFRAMES
}

\author{
Kamila Kustroń \\ Warsaw University of Technology \\ kkust@meil.pw.edupl
}

\begin{abstract}
Development design pfilosophy of airframes in all the relevant technological fields is important for the evaluation of high performance airframes best to achive high level of safety and satisfy the market needs. Maintenance cost reduction, increased aircraft availability and weight saving are goals which will be reaching by SHM systems as on-line monitoring of the structure health. Irrespective of which materials will be used in the future, the current design philosophy, which is applied today by the structural designers, will be challenged by the new design philosophy based on SHM. The most efective SHM methods are based on Lamb wave techniques. Using the based on Lamb wave techniques would be cost-effective and reliable damage detection is critical for the utilization of metal, composite and hybrid materials. Multitude of diagnostics data requires to use expert systems for effective analysis.
\end{abstract}

Key words: aircraft, airframe, metal and composite structure, degradation, durability, reliability, safety, damage detection, non destructive testing, structural health monitoring, piezoelectric, expert systems, artificial intelligence.

Streszczenie: Rozwój efektywnych metod konstruowania płatowca warunkuje powstawanie konstrukcji o lepszych osiagach przy wysokich właściwościach eksploatacyjnych. Ważnym aspektem jest obniżenie kosztów eksploatacyjnych przy wzroście współczynnika gotowości operacyjnej i oszczędnościach masowych. Te zadania mogą zostać osiagnięte poprzez efektywne zastosowanie ciagłego monitoringu (SHM) w celu wykrywania czy określania wielkości uszkodzenia. Wyniki badań w dostępnej literaturze wskazują na wysoką efektywność metod wykorzystujących własności fal Lamba. Czujniki piezoelektryczne, które można umieszczać na strukturze jak i wprowadzać $\mathrm{w}$ samą strukturę podczas procesu wytwarzania elementów konstrukcyjnych płatowca wpływają na oszczędności co do kosztów a przez to, że mają wykrywać uszkodzenia lub nadzorować ich rozprzestrzenianie podwyższają niezawodność. Techniki wykorzystujące fale Lamba są efektywne w ocenie uszkodzeń struktur metalowych, kompozytowych jak i hybrydowych. Dane zbierane z czujników o ogromnej ilości muszą być oceniane przy użyciu systemów eksperckich bazujących na technikach sztucznej inteligencji.

Słowa kluczowe: statek powietrzny, płatowiec, struktura , metalowa, kompozytowa, hybrydowa, procesy dergadacyjne, trwałość, niezawodność, bezpieczeństwo, wykrywanie uszkodzeń, badania nieniszczące, monitorowanie stanu technicznego, systemy eksperckie, sztuczna inteligencja. 


\section{SHM SUPPORTING DAMAGE TOLERANCE DESIGN PHILOSOPHY AS A CHALLENGE FOR DESIGNERS OF FUTURE AIRFRAMES}

\section{Introduction}

Durability and safety assessment methods must include research the degradation, wear and creep of advanced materials and structures, delamination and debonding in composites, investigation of cracking mechanisms and defect kinetics on the microscale or nanoscale and mechanisms of corrosive and erosive failure. The durability of an airframe depends on its design, service conditions, and the durability and damage tolerance DADT of its constituent materials. Critical materials properties include corrosion resistance, fatigue resistance, fatigue crack growth resistance, as well as toughness. The most important are cheking the best method as non-destructive testing of advanced materials and structures for finding uncontinuity of materials as well as bondings. With mentioned problems is connecting reliability of advanced structures in extreme operational regimes. So the durability, safety and reliability are the base of quality for technical objects including aircraft and airspaces in exploitation systems.

The main problem in exploitation of aircraft and airspaces is effective detecting the symtoms of structural degradation before damage. The problem of a airframe degradation was accented in catastrofic aviation history on April 28, 1988 with Aloha airlines flight accident. The event has created awareness of extensive damage caused by aging aircraft. About 36 square metres of the upper fuselage surface of the aircraft was unseparated during flight. Multiple fatigue cracks and corrosion damage were detected near the holes of the upper row of rivets in several fuselage skin lap joints. The damage done to the aircraft structure was irreversible although the casualties weren't high. During inspections of other similar aircraft detected corrosion and disbonding as well as cracking problems in the lap joints of airframes. The major problems of aging aircraft include in-service cracking of the aircraft wing upper surface, widespread fatigue damage of the various structural components, uncertainty in variable amplitude loading, overload effects of aircraft, discrete source damage induced by foreign objects, and repairs of metallic components with composite counterparts to extend the service life. 
Development design pfilosophy of airframes in all the relevant technological fields is important for the evaluation of high performance airframes best to achive high level of safety and satisfy the market needs.

The growth of the use of composite materials to replace traditional materials as primary structures remains limited by the significant inspection costs that are required to detect the appearance of internal defects. Indeed, many different damage processes can be observed in such kinds of heterogeneous media.

The innovation is an intelligent airframe optimized in terms of new materials and advanced design, and implements smart structures technologies. Beyond simply using the technologies available on the market, it is essential to develop new materials as nanostructures and nanocomposites and technologies tailored to the specific requirements. Maintenance cost reduction, increased aircraft availability and weight saving are goals which will be reaching by SHM systems as on-line monitoring of the structure health. While the maintenance benefits are usable for increasing of flight numbers, as well as for new and future aircrafts, the weight saving design benefits can be achieved only for new aircraft programs. Irrespective of which materials will be used in the future, the current design philosophy, which is applied today by the structural designers, will be challenged by the new design philosophy based on SHM.

\section{Diagnostics methods used to assess the airframe structure health}

To reduce the repair and maintenance costs, one might perform early repair on the structures before the damage grows to a dangerous size. Development of preventive methods cause increase of nondestructive diagnostics methods wchich are widely described in literature on names NDE, NDI and NDT. The non-destructive methods don't interfere with integrity of structures and give data to assesment of the structure health.

Aging aircraft structures experience various complex types of damage mechanisms that may include multiple site damage MSD, corrosion, corrosion-fatigue, and creep-fatigue. The strength and durability characteristics of aging structures or components depend on various parameters as loading spectrum, material geometry, and environment as well as complex relationships. The methods based on experiments determinated the residual strength of specimens with multisite damage intensified by corrosive environment are used to assesment durability.

Real-time non-destructive evaluation of fatigue crack damage is possible by miniaturized diagnostics system built in or on the structure with is names structural health monitoring SHM. The damage sensing system is suitable 
for health monitoring and residual life prediction in both aging and new aircraft structures. Maintenance cost reduction, increased aircraft availability and weight saving are goals which will be reaching by SHM systems as on-line monitoring of the structure health.

SHM is a new concept which coming into the designers tools. While the maintenance benefits are usable for increasing of flight numbers, as well as for new and future aircrafts, the weight saving design benefits can be achieved only for new aircraft programs. Irrespective of which materials will be used in the future, the current design philosophy, which is applied today by the structural designers, will be challenged by the new design philosophy based on SHM.

A model is generally not needed for the basic damage identification problem when using the electromechanical impedance-based method of SHM. when more information is needed for more complex functions of the SHM system, such as estimation of remaining life modeling becomes necessary. Suitable models would aid in more accurately identifying and locating damage and in designing the SHM system. Since impedance-based SHM relies on high frequency excitation of the structure using piezoelectric patches, finite element modeling may not be computationally efficient. Simulations of sensor multiplexing, high frequency response, and the inclusion of damage are presented in [1].

In [9] was defined an in situ and nondestructive method for the impact damage monitoring of carbon/epoxy laminated composites and the propagation of Lamb waves inside a stiffened aeronautical structure, and the definition of associated data processing systems was described.

Surface-bonded piezoelectric sensors can be used to monitor the mechanical behavior of structures for damage detection. A comprehensive theoretical study of the dynamic coupling between a surface piezoelectric sensor and an elastic half-plane are described in [7]. An active diagnostic system using built-in piezoelectric actuator/sensor networks was characterised in [8, 14]. The recent development of a surface fatigue crack detection technique based on the use of surface-mount piezoelectric paint sensor are presented in [6]. Polymer-based piezoelectric paints that can be directly deposited onto the surface of host structures are being utilized to make the sensor for surface crack detection. Because of its electromechanical coupling properties, voltage signals can be generated by the piezoelectric paint sensor when subjected to mechanical strain in its film plane. Results from recent development of the piezoelectric paint-based surface crack detection technique indicate that piezoelectric paint sensors with a special electrode design can potentially provide an effective method to detect fatigue cracks 
occurring in structural surfaces. To integrate sensor networks with different contours of structures, the method to fabricate a three-dimensional (3-D) diagnostic layer is developed. A large number of sensors supported on a thin flexible dielectric film, called a SMART Layer, offers a simple and efficient way to integrate a large sensor network onto a complex 3-D structure. The sensor network permanently embedded inside the composite structures can be used with either active sensing or passive sensing to monitor the health condition of a structure throughout its lifetime [5].

Several techniques have been researched for detecting damage in composite materials, however Lamb wave methods have recently re-emerged as a reliable way to locate damage in these materials [2-4, 10,12]. For both kinds of materials metals and cmposites most efective SHM methods are these based on Lamb wave techniques. Using the based on Lamb wave techniques would be cost-effective and reliable damage detection is critical for the utilization of metal, composite as well as hybrid materials.

\section{Effective methods for diagnostics data analysis}

Multitude of diagnostics data requires to use the intelligent methods for proper analysis which must be effective and take uncertainties into consideration. An expert system is feasible and that it could contribute to increased reliability of aircraft system operation without a high degree of complexity [12].

An conception of design philosophy should be used artificial inteligence to effective analysis of the lots of data from airframe SHM system (fig.1). An overview of the computational intelligence methods developed for the structural integrity assessment of aging aircraft structures are presented in [13]. Computational intelligence techniques based on artificial neural networks, inverse neural network mapping, wavelet based image processing methods, genetic algorithms, spectral element methods, and particle swarm optimization would be used for multi-site damage, corrosion, and corrosionfatigue damage data analysis for aging aircraft. 


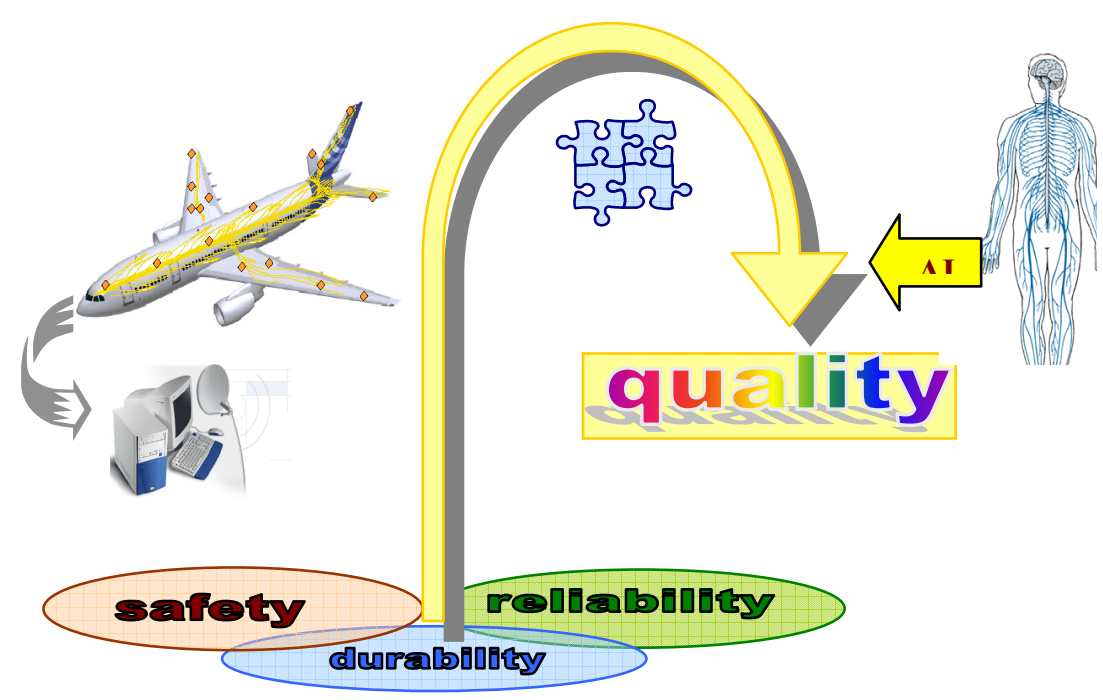

Fig.1. Design conception using expert systems based on artificial intelligence for exploitation data analysis from structural health monitoring systems built-in or bult-on the airframe

\section{Literature}

1. Peairs D. M., Inman D. J., Park G.: Circuit Analysis of Impedance-based Health Monitoring of Beams Using Spectral Elements. Structural Health Monitoring, Vol. 6, No. 1. SAGE Publications, 2007, pp. 81-94.

2. Bar-Cohen Y.: NDE of Fiber Reinforced Composite Materials-A Review. Materials Evaluation. Vol.44, 1986, pp. 446-454.

3. Chang FK.: Structural Health Monitoring: A Summary Report. Proceedings of the $2^{\text {nd }}$ International Workshop on Structural Health Monitoring. Stanford, CA, September 8-10, 1999.

4. Giurgiutiu V., Jingjing B., Zhao W.: Active Sensor Wave Propagation Health Monitoring of Bean and Plate Structures. Proceedings of the SPIE International Symposium on Smart Structures and Material. Newport Beach, California, March 5-8 2001.

5. Qing X. P., Beard S. J., Kumar A., Ooi T. K., Chang F.-K.: Built-in Sensor Network for Structural Health Monitoring of Composite Structure. Journal of Intelligent Material Systems and Structures, Vol. 18, No. 1, SAGE Publications, 2007, pp. 39-49.

6. Zhang Y.: In Situ Fatigue Crack Detection using Piezoelectric Paint Sensor. Journal of Intelligent Material Systems and Structures, Vol. 17, No. 10, SAGE Publications, 2006, pp. 843-852.

7. Wang X. D., Huang G. L.: The Coupled Dynamic Behavior of Piezoelectric Sensors Bonded to Elastic Media. Journal of Intelligent 
Material Systems and Structures, Vol. 17, No. 10, SAGE Publications, 2006,pp. 883-894.

8. Qing X. P., Chan H.-L., Beard S. J., Kumar A.: An Active Diagnostic System for Structural Health Monitoring of Rocket Engines. Journal of Intelligent Material Systems and Structures, Vol. 17, No. 7, SAGE Publications, 2006, pp.619-628.

9. Monnier T.: Lamb Waves-based Impact Damage Monitoring of a Stiffened Aircraft Panel using Piezoelectric Transducers. Journal of Intelligent Material Systems and Structures, Vol. 17, No. 5, SAGE Publications, 2006 pp. 411-421.

10. Valdez S.H.D.: Structural Integrity Monitoring of CFRP Laminates using Piezoelectric Devices. Ph.D. thesis, Imperial College of Science Technology and Medicine, September 2000.

11. Kessler S. S., Spearing S. M., Soutis C.: Optimization of Lamb Wave Methods for Damage Detection in Composite Materials. Technology Laboratory for Advanced Composites Department of Aeronautics and Astronautics Massachusetts Institute of Technology, SHM-2001.

12. Chien Y. H.: A LISP-Based Expert System for Detecting Failures in Aircraft Systems. 1984.

13. Pidaparti R.M.: Aircraft Structural Integrity Assessment through Computational Intelligence Techniques. Tech Science Press SDHM, vol.2, no.3, pp.131-147, 2006.

14. Keller E., Ray A.: Real-time nondestructive evaluation of airframe structures for health monitoring and residual life prediction. IEEE, 2001.

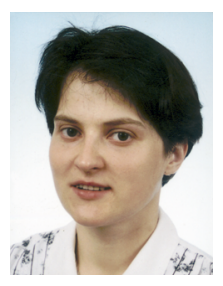

Kamila Kustroń, $\mathrm{PhD}$ Eng., is a lecturer/teaching assistant at the Department of Airplanes and Helicopters of the Warsaw University of Technology. Her scientific output comprises eleven papers presented at scientific conferences worldwide. The papers offer the Author's considerations involving structural issues and those of aircraft maintenance. The main areas of her work include aircraft ageing processes and fatigue of structural materials that find applications in aviation. 
